\title{
MARKET ORIENTATION AND THE PROPERTY DEVELOPMENT BUSINESS IN SINGAPORE
}

\author{
Jasmine Y. W. TAY $^{1}$ and Linda TAY ${ }^{2}$ \\ 1 Marketing Executive, CB Richard Ellis (Pte) Ltd., 6 Battery Road, \#32-01, \\ 049909, Singapore \\ E-mail: jasmine.tay@cbre.com.sg \\ ${ }^{2}$ Mirvac School of Sustainable Development, Faculty of Business, Technology \& Sustain- \\ able Development, Bond University, Gold Coast, QLD, 4229, Australia \\ E-mail: litay@bond.edu.au
}

Received 21 September 2006; accepted 29 January 2007

\begin{abstract}
The property development business is often regarded as one of high risk and return. As such, developing a competitive advantage is critical. Extant literature suggests that market orientation is a form of sustainable competitive advantage for businesses. This paper is an attempt to test this relationship with specific reference to a high risk business such as property development. A market orientation scale is developed to measure the degree of market orientation in property development firms. The results show that there exists a significant positive relationship for two specific dimensions of market orientation, i.e., profit orientation and responsiveness with business performance and marketing performance. Furthermore, empirical findings showed that the relationship between market orientation and marketing performance was stronger than with business performance.
\end{abstract}

KEYWORDS: Market Orientation; Property Development; Business Performance; Marketing Performance; Singapore

\section{INTRODUCTION}

Market orientation refers to a business philosophy of focusing on the coordinated activities of the organisation toward satisfying the needs of a particular market segment(s) (McCarthy and Perreault, 1984; Deng and Dart, 1994; Jaworski and Kohli, 1990 and Narver and Slater, 1990). A business is market oriented when its culture is systematically and entirely committed to the continuous creation of superior customer value.

The continuous evolvement of customer needs and wants for superior quality services and products implies the critical need to develop a sustainable competitive advantage. In order to maintain competitiveness, it is necessary that firms constantly benchmark their activities to identify industry-wide trends that may help improve the business and marketing performance. Research has shown that market orientation relates to better performance through intuitively and dynamically responding to market changes and therefore is a form of sustainable competitive advantage (Day, 1994).

The property development business is typically considered to be one of high risk and return. Nieboer (2005) found that all property investors interviewed in their study considered market orientation to be an important aspect in managing their property portfolio. Compe- 
tition within the property industry is also keen involving both big and small players. Hence, developers who want to maintain or improve their business will need to constantly produce innovative and high standards of real properties and services.

The purpose of this study is to test the relationship between market orientation and performance in the property development business. It aims to serve as a guide to attain higher efficiency and effectiveness in decisionmaking and action to be made by the senior executives within the property industry. This will enable the developer firm to create enhanced customer value through the implementation of the marketing concept and operationalise an organisational philosophy, which is primarily concerned with establishing long term customer relations.

\section{LITERATURE REVIEW}

\subsection{Defining market orientation}

There has been extensive research on market orientation (Golann, 2006; Brown et al., 2002; Jaworski and Kohli, 1993). Essentially, extant literature suggests that market orientation encompasses five dimensions - customer orientation, competitor orientation, inter-functional coordination, profit orientation and responsiveness.

Customer orientation requires sufficient understanding of the target buyer's entire value chain, gearing up to offer superior value continually to the chosen customers in terms of their needs and wants (Saxe and Weitz, 1982; Michaels and Day, 1985). It includes maintaining a good relationship with customers by improving customer satisfaction and paying close attention to both before and after-sales service. Studies by Lusch and Laczniak (1987) and Narver and Slater (1990) further provide support that organisations that track and respond to customer needs and preferences are able to better satisfy customers and hence, perform at higher levels.
Competitor orientation collects information and investigates competitors, both current and future, in the target market and shares the information within the organisation. It refers to a seller grasping the short-term strengths and weaknesses as well as long term capabilities and strategies of the present and potential competitors (Aaker, 1988; Day and Wensley, 1988). The organisation then develops a shared perspective on probable sources of competitive threats and thus develops an advantage by responding rapidly or anticipating their actions. As quoted by Deng and Dart (1994), 'management can seldom depend solely on patent or other types of monopolies or on ever-buoyant market conditions for profitability', however, they can rely on the fact that competitors will do all in their power to minimise such profits to the greatest possible extent.

Inter-functional coordination refers to the degree of co-operation between the different functions/departments within the organisation. It involves the coordination of company resources to create superior value for its customers through examining customer and competitor information. Extant literature suggests three ways to achieve effective inter-functional coordination. First is the alignment of the functional areas' performance objectives by focusing them on markets (e.g., customer satisfaction). Such market-based incentive systems motivate group-interest, leading each function/ department to participate whole-heartedly in creating superior value for its customers (Ruekert and Walker, 1987; Wind and Robertson, 1983). Second, the creation of inter-functional dependency such that each area finds it advantages to cooperate closely with the other increases the degree of coordination. Third, effective inter-functional coordination requires extreme sensitiveness and responsiveness to the perceptions and needs of all other departments.

The ultimate objective of a business in adopting market orientation is profitability (McNamara, 1972). Having a profit orientation 
is thus required for a successful business operation since it enables the firm to effectively identify a specific market target group and deal with competitor firm's offerings. Such a position can be enabled through the active application of management information systems (Melville et al., 2004). This dimension have been studied by researchers like Keith (1960), Hise (1965), Narver and Slater (1990) and Naidu and Narayana (1991).

Responsiveness is the action taken in response to assembled information regarding customers and competitors. It involves the actual production, distribution and promotion of products in such a way that elicits favourable end-customer response. An organisation can generate intelligence and disseminate it internally; however, unless it responds to market needs, very little may be accomplished (Kohli and Jaworski, 1990). In the field study Jaworski and Kohli (1993), responsiveness to market developments was found to be encouraged when there is a willingness to take calculated risks on the part of senior managers.

\subsection{Market orientation and performance}

Super-normal market performance is defined as attaining a high level of profitability, customer retention, sales growth and new product success. An organisation that yearns to attain super-normal business performance is required to create a sustainable competitive advantage (SCA) (Aaker, 1988). To do so, it must create superior value for its customers. A market-oriented seller thus acknowledges that additional benefits should be passed on to buyers through reduction in buyers' total acquisition and use cost results in many potential sources of SCA (Aaker, 1988; Hall, 1980). Long-run performance is maximised by an organisation that continuously reviews alternative sources of SCA that will most effectively create superior value for its current and future target buyers. As such, a market-oriented firm is associated with a firm that incurs low operating and business expenses due to lesser product failures because they are able to consistently correct quality control problems. This subsequently leads to better business and marketing performance in terms of higher return on investment. Market orientation is therefore a dynamic capability that firms can develop to achieve a sustainable competitive advantage (Ching and Hsu, 2006).

Atuahene-Gima (1995) defines a satisfied customer as an individual that is greatly influenced by the quality of product and the services provided to them. Drucker (1954) asserted that the creation of a satisfied customer is the sole justification for a business purpose. Day (1994) suggested that satisfied customers will spread the good word to other potential customers and keep coming back to the organisation, providing it with more business and thus improve the business and marketing performance. Reichheld and Sasser (1990) also observed that a 5 percent growth in customer retention might enhance the firm's profit levels from 25 percent to 85 percent.

Furthermore, Han et al. (1998) proposed that a market-oriented firm is likely to lead to more innovation, which, in turn, is likely to lead to achievement of superior business and marketing performance. Besides, a significant amount of management literature also supports the idea of innovation leading to superior business performance (Agarwal et al., 2003, Khan and Manopichetwattana, 1989; Zahra et al., 1988).

\section{HYPOTHESES}

Positive relationship between market orientation and business performance have been found in several countries, e.g., United States (Green, et al., 2005), United Kingdom (Tay and Morgan, 2002), Japan (Deshpande et al., 1993), Taiwan (Chang and Chen, 1994), Australia (Athuane-Gima, 1995), among others. The premise for the positive relationship is that firms that take efforts to understand customers' needs in order to fulfil those needs develop better products/services with less defects which 
results in reduced operational cost, and therefore an enhanced performance (Singh, 2003).

Conversely, Diamantopoulos and Hart (1993) in the UK found an unfavourable relationship between market orientation and business performance. Bhuian (1997) in Arabia, Greenley (1995) in UK and Appiah-Adu (1998) in Ghana gathered no significant association between market orientation and business performance. Singh (2003) expressed that such contrast in findings might be due to one of the following factors: market orientation might be uneconomical in various market conditions; the possibility of a lagged relationship between market orientation and performance that was not identified in the cross-sectional study; and, the cost to implement the market orientation override the benefits that could be achieved.

Specifically in the property industry, Tse (1998) found no significant relationship between market orientation and business performance of large property companies in Hong Kong. Consequently, such diverse results found in the above various researches prompts a research to study the relationship between market orientation and performance of property development firms in Singapore. In this study, the impact of market orientation on both business and marketing performance are examined.

From the five dimensions discussed, we develop the hypotheses:

$\mathrm{H}_{1}$ : The greater the level of customer orientation of a developer firm, the higher the business and marketing performance.

$\mathrm{H}_{2}$ : The greater the level of competitor orientation of a developer firm, the higher the business and marketing performance.

$\mathrm{H}_{3}$ : The greater the level of inter-functional coordination of a developer firm, the higher the business and marketing performance.

H4: The greater the level of profit orientation of a developer firm, the higher the business and marketing performance.
$\mathrm{H}_{5}$ : The greater the level of responsiveness of a developer firm, the higher the business and marketing performance.

\section{RESEARCH METHODOLOGY}

\subsection{Original market orientation scales}

In the extant literature, research pertaining to market orientation has diverged to two main categories of market orientation scales, i.e., those of Narver and Slater (1990) and Jaworski and Kohli (1993). These generic measuring instruments are briefly discussed below to provide backdrop to the following section 4.2 in which a separate market orientation scale will be developed specifically for property development organisations.

a) Narver and Slater (1990)

The instrument was tested on 113 strategic business units (SBU) of a major western corporation dealing with forest products division. Market orientation was hypothesised to comprise customer orientation, competitor orientation, inter-functional coordination, a longterm focus and a profit objective. Respondents were required to go through a 33-item scale and then record their answers on a 7-point Likert scale with 1 indicating that the SBU does not engage in the practice at all while 7 represents that SBU engages in it to a very great extent. The reliability analysis from the test is found in Table 1.

Table 1. Cronbach alpha from Narver and Slater (1990)

\begin{tabular}{lll}
\hline Dimension & $\begin{array}{l}\text { Cronbach } \\
\text { alpha } \\
\text { Sample 1 }\end{array}$ & $\begin{array}{l}\text { Cronbach } \\
\text { alpha } \\
\text { Sample 2 }\end{array}$ \\
\hline Customer orientation & 0.85 & 0.87 \\
Competitor orientation & 0.72 & 0.73 \\
Interfunctional & 0.71 & 0.73 \\
coordination & & \\
Long-term horizon & 0.48 & 0.41 \\
Profit emphasis & 0.14 & 0.00 \\
\hline
\end{tabular}


b) Jaworski and Kohli (1993)

Market orientation was measured through a 32 -item scale. Items were grouped into 3 core criteria; ten items pertaining to market intelligence generation, eight to intelligence dissemination and fourteen to responsiveness. Each individual item was scored upon a 5-point Likert scale ranging from "strongly disagree to strongly agree". Business and marketing performance were measured using both judgmental and objective measures. Judgemental measures were assessed by informants by rating their business and marketing performance using a 7-point scale ranging from poorer to excellence compared to the nearest competitor while the objective measures were rated by informants on their organisation's market share compared to the served market. The reliability analysis from the test is found in Table 2.

Table 2. Cronbach alpha from Jaworski and Kohli (1993)

\begin{tabular}{ll}
\hline Dimension & Conbach alpha \\
\hline Intelligence generation & 0.71 \\
Intelligence dissemination & 0.82 \\
Responsiveness & 0.78 \\
\hline
\end{tabular}

\subsection{Development of market orientation scale for property development firms}

To maximise the insights from the above two pioneering studies, this study seeks to synthesise the results to produce a market orientation instrument to be used in the property development business. A review of the instruments by the two different sets of researchers showed some overlapping questions (placed in different dimensional heading). As such, questions that were either similar in the two different instruments or questions that had low Cronbach Alpha scores were eliminated. As suggested by Nunally (1978), reliability exceeding 0.7 are recommended for research. Hence, Cronbach Alpha scores above 0.7 from the original studies were selected. Five market orientation dimensions items that collectively define the scope of the market orientation construct were selected. Thereafter, some items were revised in specific relation to practices within the local property development business (please refer to the * items in the Appendix). To ensure a parsimonious scale, academic inputs were also sought. The robustness of the adapted scale for the property development industry is further reinforced by subjecting it to reliability and validity tests in the following sections. The final count for the measurement items was 29 .

\subsection{Operationalisation of variables}

The market orientation scale variables are operationalised by a Likert scale of seven instead of the original scale of five. The anchors of the standard scale are labelled with 'strongly disagree' (1) to 'strongly agree' (7). Such extension ensured greater sensitivity and comparability with other scales.

This study operationalises business performance using six performance indicators. They are market share, sales growth, average profits per project, return on investment (ROI), number of profitable new properties developed/ services provided and overall business performance. Marketing performance was measured through five indicators consisting of identifying new opportunities, raising awareness of firms, client satisfaction, client retention and cross-selling of new properties developed and services provided to existing clients. Respondents were asked to assess their firm's performance in relation to their major direct competitor. Both measures were measured according to a 7-point Likert scale ranging from -3 being much lower performance, 0 being no difference in performance and +3 being much superior performance.

\subsection{Data collection}

Nunally (1978) opined that subjects used should be those whom the instrument devel- 
oped are intended for. The level of analysis in this study is the overall organisation's degree of market orientation rather than of a specific department within the organisation. Henceforth, the modified questionnaires were directed to $\mathrm{CEO}$ of the organisations. They are the "thought" leaders of the organisation, and, often also act as the architect of the organisation's business philosophy. Another reason for addressing the questionnaires to the CEO is that where the CEO is not available to respond, he/she would be in the best position to identify a subordinate who is well acquainted with the organisation's business operations and culture.

The data for testing the hypotheses were collected via mail survey in late 2003 . The target population was the property developer firms in Singapore that developed retail, commercial, industrial and residential properties in Singapore as well as developers who develop and operate hospitality businesses. This target range varied in size, annual gross turnover and geographic location as the objective of this study was to develop a scale suitable to be used for developer firms that had active real estate business dealing in Singapore. In order to ensure the firms surveyed have business operations in Singapore, the firms were selected from a list of developers registered under the Real Estate Developers Association of Singapore (REDAS) and which had offices located in Singapore. This resulted in the identification of 145 firms.

A questionnaire and a personal letter together with a pre-paid return envelope were mailed to the developer firms addressed to the CEO either by name or title. A three-wave mailing procedure was adopted to improve the response rate. The questionnaires were first sent out with an accompanying cover letter and a self addressed reply-paid envelope. A reminder postcard was sent a week later and a third mailing was made to firms that had not replied three weeks after the first mailing. Through this procedure, 41 complete and usable surveys were received. This corresponds to an effective response rate of $28.3 \% .12$ questionnaires were returned due to one of the following reasons: the company has moved, the company no longer exists or the company has been inactive in real estate businesses in recent years.

\subsection{Reliability analysis}

Cronbach's alpha is a coefficient of reliability mathematically defined as the proportion of the variability in the responses to the survey that is the result of differences in the respondent. Cronbach's alpha estimate of reliability is computed based on the reliability of a test relative to other tests with same number of items, and measuring the same construct of interest. Nunally (1978) recommends a coefficient of 0.7 as the basis for determining the reliability of each dimension. In this study, a stricter scale purifier coefficient of 0.75 is employed to develop a more precise instrument (Churchill, 1979). Nunally (1978) also recommended an item-to-total correlation of at least 0.45 as the threshold for deletion of item from the scale.

Table 3 shows that the reliability coefficients were fairly uniform, ranging from 0.7991 to 0.9028 for the five dimensions while 0.9278 to 0.9656 for the business and marketing performance measures with all the items exceeding the threshold alpha value of 0.75 . Five items out of the original 29 were deleted to improve the Cronbach Alpha and therefore improving the reliability of the instrument. This leaves 24 items in the scale.

\subsection{Validity assessment}

Validity refers to the degree in which a study accurately reflects the specific concept that the researcher is attempting to measure. While reliability is concerned with the accuracy of the actual measuring instrument or procedure, validity is concerned with the study's success at measuring what the researchers intended to measure. 
Table 3. Summarised reliability analysis results

\begin{tabular}{|c|c|c|c|c|c|c|}
\hline Dimension & Items & $\begin{array}{l}\text { Corrected } \\
\text { item-to-total } \\
\text { correlation } \\
\end{array}$ & $\begin{array}{l}\text { Cronbach } \\
\text { alpha if items } \\
\text { is deleted }\end{array}$ & $\begin{array}{l}\text { Cronbach } \\
\text { alpha of } \\
\text { dimension }\end{array}$ & $\begin{array}{l}\text { Deleted } \\
\text { items }\end{array}$ & $\begin{array}{l}\text { Cronbach alpha of } \\
\text { dimension of } \\
\text { deletion of items }\end{array}$ \\
\hline \multirow{8}{*}{$\begin{array}{l}\text { Customer } \\
\text { orientation }\end{array}$} & Cust_01 & 0.8148 & 0.8783 & \multirow[t]{8}{*}{0.9028} & \multirow[t]{8}{*}{ Cust_06 } & \multirow[t]{8}{*}{0.9126} \\
\hline & Cust_02 & 0.6681 & 0.8963 & & & \\
\hline & Cust_03 & 0.8448 & 0.8766 & & & \\
\hline & Cust_04 & 0.7476 & 0.8852 & & & \\
\hline & Cust_05 & 0.6394 & 0.8959 & & & \\
\hline & Cust_06 & 0.4306 & 0.9126 & & & \\
\hline & Cust_07 & 0.7410 & 0.8869 & & & \\
\hline & Cust_08 & 0.7395 & 0.8879 & & & \\
\hline \multirow{5}{*}{$\begin{array}{l}\text { Competitor } \\
\text { orientation }\end{array}$} & Comp_01 & 0.4424 & 0.8151 & \multirow[t]{5}{*}{0.8092} & \multirow[t]{5}{*}{ Comp_01 } & \multirow[t]{5}{*}{0.8151} \\
\hline & Comp_02 & 0.5772 & 0.7778 & & & \\
\hline & Comp_03 & 0.7596 & 0.7241 & & & \\
\hline & Comp_04 & 0.7244 & 0.7287 & & & \\
\hline & Comp_05 & 0.4980 & 0.8007 & & & \\
\hline \multirow{6}{*}{$\begin{array}{l}\text { Interfunctional } \\
\text { co-ordination }\end{array}$} & Intf_01 & 0.4717 & 0.7859 & \multirow[t]{6}{*}{0.7991} & \multirow[t]{6}{*}{ Intf_03 } & \multirow[t]{6}{*}{0.8139} \\
\hline & Intf_02 & 0.5552 & 0.7740 & & & \\
\hline & Intf_03 & 0.3327 & 0.8139 & & & \\
\hline & Intf_04 & 0.5921 & 0.7595 & & & \\
\hline & Intf_05 & 0.6684 & 0.7408 & & & \\
\hline & Intf_06 & 0.7542 & 0.7142 & & & \\
\hline \multirow{3}{*}{$\begin{array}{l}\text { Profit } \\
\text { orientation }\end{array}$} & Prof_01 & 0.6485 & 0.8046 & \multirow[t]{3}{*}{0.8281} & \multirow[t]{3}{*}{ - } & \multirow[t]{3}{*}{0.8281} \\
\hline & Prof_02 & 0.7562 & 0.6962 & & & \\
\hline & Prof_03 & 0.6605 & 0.7869 & & & \\
\hline \multirow[t]{7}{*}{ Responsiveness } & Resp_01 & 0.5284 & 0.8135 & \multirow[t]{7}{*}{0.8274} & Resp_02 & \multirow[t]{7}{*}{0.8653} \\
\hline & Resp_02 & 0.4319 & 0.8245 & & Resp_03 & \\
\hline & Resp_03 & 0.3037 & 0.8577 & & & \\
\hline & Resp_04 & 0.6552 & 0.7900 & & & \\
\hline & Resp_05 & 0.6475 & 0.7914 & & & \\
\hline & Resp_06 & 0.7463 & 0.7774 & & & \\
\hline & Resp_07 & 0.8125 & 0.7603 & & & \\
\hline \multirow{6}{*}{$\begin{array}{l}\text { Business perfor- } \\
\text { mance }\end{array}$} & Bzper_01 & 0.8008 & 0.9691 & \multirow[t]{6}{*}{0.9656} & \multirow[t]{6}{*}{-} & \multirow[t]{6}{*}{0.9656} \\
\hline & Bzper_02 & 0.9440 & 0.9533 & & & \\
\hline & Bzper_03 & 0.8543 & 0.9630 & & & \\
\hline & Bzper_04 & 0.8929 & 0.9586 & & & \\
\hline & Bzper_05 & 0.9226 & 0.9554 & & & \\
\hline & Bzper_06 & 0.9339 & 0.9542 & & & \\
\hline \multirow{5}{*}{$\begin{array}{l}\text { Marketing } \\
\text { performance }\end{array}$} & Mktper_01 & 0.8375 & 0.9060 & \multirow[t]{5}{*}{0.9278} & - & 0.9278 \\
\hline & Mktper_02 & 0.8105 & 0.9130 & & & \\
\hline & Mktper_03 & 0.7079 & 0.9299 & & & \\
\hline & Mktper_04 & 0.8808 & 0.8971 & & & \\
\hline & Mktper_05 & 0.8347 & 0.9078 & & & \\
\hline
\end{tabular}


To demonstrate validity, factor analysis was performed in this study to determine and confirm whether the 24 items collapse and fit into the 5 dimensions. The minimum factor loading of 0.45 as recommended by Churchill et al. (1979), was used as the basis for collating the items that pertain to their respective dimension. Only items with the highest loadings are harmonised into the respective dimension. Also, any items that did not show a discrete distinction to fit into any of the 5 dimensions were eliminated. The results are presented in Table 4 below.

From the results, it is observed that 6 factors were derived through factor analysis. The items were fit into their respective dimensions based on the highest loading score. However, some items were reallocated to a more suitable dimension. For instance, Intf_02 and Intf_04 were transferred to the competitor orientation dimension. The transfer of Intf_02 was justifiable since preparation of a good business plan strategy (Intf_02) takes into account competitor's activities and strategies. Intf_04 was loaded both onto its original dimension and competitor orientation. An examination of Intf_04 shows that there is in fact a relation between these two dimensions. However the question was based on whether one department is quick enough to alert another department when there is news of competitors, so the item was left to remain within the inter-

Table 4. Summarised Validity Analysis Results

\begin{tabular}{|c|c|c|c|c|c|c|}
\hline Factors & & & & & & \\
\hline & 1 & 2 & 3 & 4 & 5 & 6 \\
\hline Cust_01 & 0.866 & & & & & \\
\hline Cust_02 & 0.776 & & & & & \\
\hline Cust_03 & 0.917 & & & & & \\
\hline Cust_04 & 0.840 & & & & & \\
\hline Cust_05 & 0.665 & & & & & \\
\hline Cust_07 & 0.745 & & & & & \\
\hline Cust_08 & 0.757 & & & & & \\
\hline Comp_02 & & & 0.524 & & & \\
\hline Comp_03 & & 0.860 & & & & \\
\hline Comp_04 & & 0.874 & & & & \\
\hline Comp_05 & & 0.569 & & & & \\
\hline Intf_01 & & & & & 0.795 & \\
\hline Intf_02 & & 0.568 & & & & \\
\hline Intf_04 & & 0.471 & 0.672 & & & \\
\hline Intf_05 & & & 0.707 & & & \\
\hline Intf_06 & & & 0.540 & & 0.495 & \\
\hline Prof_01 & & & & 0.814 & & \\
\hline Prof_02 & & & & 0.893 & & \\
\hline Prof_03 & & & & 0.764 & & \\
\hline Resp_01 & & & 0.577 & & & \\
\hline Resp_04 & & & & & & 0.815 \\
\hline Resp_05 & & & & & & 0.806 \\
\hline Resp_06 & & & & & & 0.857 \\
\hline Resp_07 & & & & & & 0.858 \\
\hline
\end{tabular}

Items in bold are successfully loaded while items in italic are deleted. 
functional coordination dimension. Moreover, based on the highest loading factor, the factor loading score was higher in its original dimension (0.672) than in competitor orientation dimension (0.471).

Similarly Resp_01 and Comp_02 were loaded onto the inter-functional coordination dimension. However, Comp_02, which measures the frequency of the employees that collect competitors marketing data in order to help direct the firm's marketing plan was not related to the inter-functional dimension, hence, it was dropped. Similarly Resp_01 was dropped since the question was based on the responsiveness of the firm to competitor's price changes as well as changes in customer's needs.

Interestingly, a new dimension evolved that contained both Intf_01 and Intf_06. This meant that there were two separate dimensions measuring inter-functional coordination; one that involves Intf_04, Intf_05 and Intf_06 while the other includes Intf_01 and Intf_06. After reviewing each of these questions, it was found that there was a slight difference in the formulation as Intf_04, Intf_05 and Intf_06 involved discussing and alerting departments on new information gathered. In addition, Intf_06 when loaded with Intf_04 and Intf_05 was higher (0.540) than when loaded with Intf_01 (0.495). Hence, it was dropped from the dimension that involved Intf_01.

An examination of Intf_01 was done and it was found that Intf_01 was based on sharing of marketing information organisational-wide. Marketing information, in the case of real estate development are highly sensitive and a source of advantage over competitors. For ex- ample, sale prices and marketing strategy of new developments are not revealed to the sales-force till the launch date itself. Consequently, marketing information may not be so freely shared with the other department to avoid any leakage of price information to competitors. Further, Intf_01 is a reversed-phrased question and a limitation to such phrasing is that respondents tend to emphasise their answers more strongly. As such, recoded answers would appear to be a compounded problem resulting in differences from what the original scale was measuring. For these reasons, the dimension containing only Intf_01 was eliminated as it was ambiguous to accept a factor consisting of only 1 item.

From the 24 items, three items, namely Comp_02, Intf_01 and Resp_01 were deleted as it did not fall into any of the dimensions. Table 5 is a reorganisation of the 21 items allocated into 5 dimensions.

\section{RESULTS}

\subsection{Profile of respondents}

The responses received showed a fair distribution in terms of firm size with $29.3 \%$ of the developers employing between 101 and 200 employees and $34.2 \%$ employing less then 100 employees. In addition, majority of the respondent firms are established in the property development business with $63.4 \%$ operating for more than 10 years in the industry. The respondents were also mostly senior executives in the firms and hence are able to provide strategic responses sought in the questionnaire.

Table 5. Factor reorganisation

\begin{tabular}{ll}
\hline Dimension & Items \\
\hline Customer orientation & Cust_01, Cust_02, Cust_03, Cust_04, Cust_05, Cust_07, Cust_08 \\
Competitor orientation & Comp_03, Comp_04, Comp_05, Intf_02 \\
Inter-functional coordination & Intf_04, Intf_05, Intf_06 \\
Profit orientation & Prof_01, Prof_02, Prof_03 \\
Responsiveness & Resp_04, Resp_05, Resp_06, Resp_07, \\
\hline
\end{tabular}




\subsection{Hypothesis testing}

To test the five hypotheses, simple linear regression was performed to determine if there exists a linear relationship between the dependent variable (business and marketing performance) and the independent variable (customer orientation, competitor orientation, inter-functional coordination, profit orientation and profit orientation). Table 6 presents a summary from the linear regression test.

The results regressed support both hypotheses 4 and 5. That is, responsiveness of a developer firm is positively and linearly related to business ( $\left.b=0.253, R^{2}=0.498\right)$ and marketing $\left(b=0.380, R^{2}=0.509\right.$ ) performance. Similarly profit orientation of a developer firm is positively and linearly related to business $\left(\mathrm{b}=0.199, \mathrm{R}^{2}=0.512\right)$ and marketing $(\mathrm{b}=$ $\left.0.232, R^{2}=0.460\right)$ performance at a 0.05 level of significance.

For $\mathrm{H}_{1}, \mathrm{H}_{2}$ and $\mathrm{H}_{3}$, the null hypothesis is not rejected. However, it does not conclude that $\mathrm{b}_{1}=0$. Instead additional data might indicate that $b_{1}$ differs from zero, or a more complex relationship may exist between $\mathrm{X}$ and $\mathrm{Y}$, thus requiring a fitting of a model other than a straight line model. Therefore it is interpreted that customer orientation, competitive orien- tation and Interfunctional coordination of a developer firm is not linearly related to business and marketing performance.

\subsection{Correlation analysis}

To produce further insights from the data collected, a correlation analysis using the Pearson's test is conducted between the individual dimensions of market orientation and the two performance indicators, i.e., business and marketing performance. As suggested in Alvin and Ronald (2000), associative relationship is best tested using correlation analysis. Table 7 presents the results.

Since Pearson correlation is in fact a measure of strength of linear relationship between two quantitative variables, the resulting correlation results should be consistent with the usage of simple linear regression. Indeed, the responsiveness dimension showed statistically significant results at the 0.01 significance level for all 11 performance indicators. Profit orientation dimension also showed significant results at the 0.01 significance level except two indicators, identifying new business opportunities and cross-selling of new properties developed/services provided to existing clients which was significant at the 0.05 level.

Table 6. Regression results

\begin{tabular}{lllll}
\hline Independent variables & Dependent variables & $\mathrm{R}^{2}$ & Beta & Significance \\
\hline Customer orientation & Overall business performance & 0.019 & 0.170 & 0.386 \\
& Overall marketing performance & 0.075 & 0.280 & 0.082 \\
& & & & \\
Competitor orientation & Overall business performance & 0.046 & -0.253 & 0.176 \\
& Overall marketing performance & 0.003 & 0.005 & 0.751 \\
& & & & \\
Inter-functional & Overall business performance & 0.031 & 0.178 & 0.267 \\
coordination & Overall marketing performance & 0.078 & 0.234 & 0.077 \\
& & & & 0.003 \\
Profit orientation & Overall business performance & 0.199 & 0.512 & 0.001 \\
& Overall marketing performance & 0.232 & 0.460 & \\
& & & & 0.001 \\
Responsiveness & Overall business performance & 0.253 & 0.498 & 0.000 \\
\hline
\end{tabular}


Table 7. Pearson correlation : market orientation dimension and performance indicators

\begin{tabular}{|c|c|c|c|c|c|c|}
\hline \multicolumn{2}{|c|}{ Indicators / Dimension } & \multirow{2}{*}{$\begin{array}{l}\begin{array}{l}\text { Customer } \\
\text { orientation }\end{array} \\
0.255\end{array}$} & \multirow{2}{*}{$\begin{array}{l}\begin{array}{l}\text { Competitor } \\
\text { orientation }\end{array} \\
-0.337^{*}\end{array}$} & \multirow{2}{*}{$\begin{array}{l}\begin{array}{l}\text { Inter-functional } \\
\text { coordination }\end{array} \\
0.060\end{array}$} & \multirow{2}{*}{$\begin{array}{l}\begin{array}{l}\text { Profit } \\
\text { orientation }\end{array} \\
0.254\end{array}$} & \multirow{2}{*}{$\begin{array}{l}\begin{array}{l}\text { Respon- } \\
\text { siveness }\end{array} \\
0.515^{* *}\end{array}$} \\
\hline \multirow{6}{*}{ 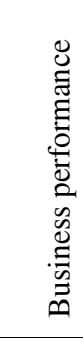 } & Market share & & & & & \\
\hline & Sales growth & 0.143 & -0.170 & 0.177 & $0.441 * *$ & $0.535 * *$ \\
\hline & Average profits /project & 0.246 & -0.004 & 0.255 & $0.471 * *$ & $0.485^{* *}$ \\
\hline & ROI & 0.099 & -0.092 & 0.107 & $0.412 * *$ & $0.446 * *$ \\
\hline & $\begin{array}{l}\text { Profitable } \\
\text { developments }\end{array}$ & 0.018 & -0.249 & 0.152 & $0.490 * *$ & $0.413 * *$ \\
\hline & $\begin{array}{l}\text { Overall business } \\
\text { performance }\end{array}$ & 0.032 & -0.256 & 0.150 & $0.469 * *$ & $0.417 * *$ \\
\hline \multirow{5}{*}{ 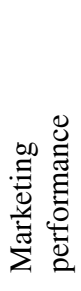 } & $\begin{array}{l}\text { Identify new } \\
\text { opportunities }\end{array}$ & $0.400 * *$ & 0.260 & $0.362 *$ & $0.366^{*}$ & $0.477 * *$ \\
\hline & $\begin{array}{l}\text { Raising awareness of } \\
\text { firm }\end{array}$ & $0.463 * *$ & 0.221 & $0.326^{*}$ & $0.448 * *$ & $0.546 * *$ \\
\hline & Client satisfaction & $0.501 * *$ & $0.374 *$ & $0.517 * *$ & $0.444 * *$ & $0.482 * *$ \\
\hline & Client retention & 0.242 & 0.095 & 0.180 & 0.198 & $0.605 * *$ \\
\hline & Cross-selling & 0.258 & 0.103 & 0.261 & $0.315^{*}$ & $0.592 * *$ \\
\hline
\end{tabular}

** Correlation significant at 0.01 level (2-tailed)

* Correlation significant at 0.05 level (2-tailed)

There exists significant relationship between customer orientation with three marketing performance indicators, 'identify new opportunities', 'raising awareness of firm' and 'client satisfaction' at the 0.01 significance level. This suggests that developers who are more customer-oriented are able to create superior customer satisfaction, the good word spread by the customers creates greater public awareness of the firm and helps develop new business opportunities for the firm. As such, there might be better chances of sales growth in the long term.

Similarly, inter-functional co-ordination is positively associated with three marketing performance indicators. Specifically, 'identify new opportunities' and 'raising awareness of firm' were significant at the 0.05 level and 'client satisfaction' was significant at the 0.01 level. This dimension shows that if a developer desires to improve its marketing performance, it should be inter-functionally coordinated; the firm requires inter-departmental dissemination of any information with regards to client's feedback, competitor activities, etc. to be very effi- cient. The engagement of this dimension helps the firm to acquire knowledge required by each individual department efficiently. Effective communication and well-coordinated business plan strategies thus helps the firm to satisfy customers better. An efficient team thus enhance the developer's chances of identifying new opportunities timely as well as create greater public awareness of the firm.

There was also significant correlation between two performance indicators, 'client satisfaction' and 'market share' with the competitor orientation dimension. Both the correlations were rather weak at the 0.05 level significant levels. Such correlation implies that the more competitor-oriented the developer, the more it is able to satisfy their clients since they are constantly reviewing the competitor's action and reacting to their moves. In any case if the developer decides to react to competitor's reduction in price, clients will be more satisfied since they have more to gain in such circumstances. However, the more competitororiented the developer, the lower its market share since over-concentrating by always re- 
acting to competitor's actions will make the developer lose its focus of the unique flavour that its development/service can provide for.

Even though the alternative hypothesis of hypothesis 1,2 and 3 were rejected, the null hypotheses are also not accepted. The reason is that there exists a linear correlation between the customer orientation, competitor orientation and inter-functional coordination with four of the performance indicators. It thus shows that, the greater the level of customer orientation of a developer firm, the better its marketing performance in terms of identifying new opportunities, raising awareness of firm and client satisfaction, albeit a weak correlation. Similarly, the greater the inter-functional coordination of a developer, the more superior is its marketing performance in terms of identifying new opportunities, raising awareness of firm and client satisfaction. Competitor orientation showed statistical significance with client satisfaction in a positive association while a negative association was registered with market share.

\section{CONCLUSIONS}

In essence, the findings indicate a stronger relationship between market orientation and marketing performance rather than business performance for Singapore property development firms. The less than strong relationship between market orientation and business performance suggests that there may be moderating factors in the relationship between market orientation and business performance. An empirical study by Tay (2002) on the business performance of surveying firms found marketing performance to have a strong and significant direct effect on business performance. In turn, marketing performance is largely dependent on the firm's degree of market orientation. This finding is also supported in this study.

The overall results supported two of the hypothesis, $\mathrm{H}_{4}$ and $\mathrm{H}_{5}$, i.e. the greater the level of profit orientation of a developer firm, the higher the business and marketing perform- ance $\left(\mathrm{H}_{4}\right)$ and, the greater the level of responsiveness of a developer firm, the higher the business and marketing performance $\left(\mathrm{H}_{5}\right)$. The findings are intuitive because the greater the profit orientation implies a greater emphasis on the development of a good management information system. Such an emphasis therefore has a direct relationship with good performance since knowledge is the critical ingredient of effective business strategising. Thus, hypothesis 4, i.e., the higher the level of profit orientation of a developer firm, the better its business and marketing performance was supported.

The fifth hypothesis, i.e. the more responsive the developer firm the better its business and marketing performance was also supported. Active response to customer and competitor information through product design, production, distribution and promotion provides an edge over the competitors and therefore can lead to improvement in sales and profits. However, simply generating customer and competitor information without analysing and responding to it will not help to improve the business/marketing performance. Moreover, as stated in the literature review, responsiveness involves responding to all the other four dimensions. Hence, the engagement of responsiveness implicitly proves its correlation of improved business and marketing performance.

Although there was no overall positive relationship found between customer orientation, competitor orientation and inter-functional coordination and performance (both business and marketing), there were moderately strong relationships between these three market orientation dimensions and individual performance indicators such as identifying new opportunities, client satisfaction and raising firm awareness.

\subsection{Implications for managers}

The central message arising from the results of this study for managers is the impor- 
tance of market orientation for improving performance. Specifically, the results illustrate the relevance of the market orientation concept for the property development business. It reinforces the findings of Jaworski and Kohli (1993) by showing that to improve marketing and business performance, market orientation needs to be implemented in all its three dimensions, i.e., intelligence generation, intelligence dissemination and responsiveness. Firstly, the results showed that the most important intelligence required pertains to customer. Secondly, the intelligence needs to be disseminated effectively through good interfunctional co-ordination. Finally, the firm needs to act on the information through targeted strategies and this is facilitated by having a good management information system.

\section{REFERENCES}

Aaker, D. A. (1988) Strategic Market Management, $2^{\text {nd }}$ edition, New York: John Wiley, New York.

Agarwal, S., Erramili, M. K. and Dev, C. S. (2003) Market Orientation and Performance in Service Firms: Role of Innovation. Journal of Services Marketing, 17(1), p. 68-82.

Alvin, C. B. and Ronald F. B. (2000) Marketing Research, $3^{\text {rd }}$ edition, New Jersey: Prentice Hall International, Inc.

Appiah-Adu, K. (1998) Market Orientation and Performance: Empirical Tests in a Transition Economy. Journal of Strategic Marketing, 6(1), p. 25-45.

Atuahene-Gima, K. (1995) An exploratory analysis of the impact of Market Orientation on new product performance. A Contingency Approach, Journal of Production Innovation Management, 12(4), p. 275-293.

Bhuian, S.N. (1997) Exploring market orientation in banks: An empirical examination in Saudi Arabia. Journal of Services Marketing, 11(5), p. 317-328.

Brown, T. J., Mowen, J. C., Donovan, D. T. and Licata, J. W. (2002) The customer orientation of service workers: Personality trait effects on self-and supervisor performance ratings. Journal of Marketing Research, 39(1), p. 110-119.
Chang, T., and Chen, S. (1994) The impact of market orientation on total offering quality and business profitability. American Marketing Association Conference Proceedings, Chicago, USA.

Ching, H. Y. and Hsu, T. T. (2006) The impact of dynamic capabilities with market orientation and resource-based approaches on NPD project performance. The Journal of American Academy of Business, 8(1), p. 215-229.

Churchill, G. A. (1979) A paradigm for developing better measures of marketing constructs. Journal of Marketing Research, 16, February, p. 23-37.

Day, G. S. and Wensley R. (1988) Assessing Advantage: A framework for diagnosing competitive superiority. Journal of Marketing, April, p. 1-20.

Day, G. S. (1994) The capabilities of market-driven organisations. Journal of Marketing, 58, October, p. 37-52.

Deng, S. and Dart, J. (1994) Measuring market orientation: A multi factor, multi-item approach. Journal of Marketing Management, 10(8), p. 725-742.

Deshpande, R., Farley, J. and Webster, F. (1993) Corporate culture, customer orientation, and innovation in Japan firms: A quadrat analysis. Journal of Marketing, 57, January, p. 23-27.

Diamanthopoulos, A. and Hart, S. (1993) Linking market orientation and company performance: Preliminary evidence on Kohli and Jaworski's framework. Journal of Strategic Marketing, 1(2), p. 93-122.

Drucker, P. (1954) The Practice of Management, New York: Harper and Row.

Golann, B. (2006) Achieving growth and responsiveness: process management and market orientation in small firms. Journal of Small Business Management, 44(3), p. 369-385.

Green, K. W. Jr., Inman, R. A.. Brown, G. and Willis, T. H. (2005) Market orientation: relation to structure and performance. Journal of Business \& Industrial Marketing, 20(6), p. 276-284.

Greenley, G. E. (1995) Market orientation and company performance: empirical evidence from UK companies. British Journal of Management, 6(1), p. 1-13.

Hall, W. K. (1980) Survival strategies in a hostile environment. Harvard Business Review, 58(5), p. $75-85$. 
Han, J. K., Kim, N. and Srivastava, R. J. (1998) Market Orientation and Organisationa1 Performance: Is innovation a missing link? Journal of Marketing, 62(4), p. 30-45.

Hise, R. T. (1965) Have manufacturing firms adopted the marketing concept? Journal of Marketing, October, p. 9-12.

Jaworski, B. J. and Kohli, A. K. (1993) Market orientation: Antecedents and Consequences. Journal of Marketing, 57, July, p. 53-70.

Keith, R. J. (1960) The marketing revolution. Journal of Marketing, 54, April, p. 35-38.

Khan, A. M. and Manopichetwattana, V. (1989) Innovative and non innovative small firms: types and characteristics. Management Science, 35, May, p. 597-606.

Kohli, A. K. and Jaworski, B. J. (1990) Market orientation: The construct, research propositions, and managerial implications. Journal of Marketing, 54, April, p. 1-18.

Lusch, R. F. and Laczniak, G. R. (1987) The evolving marketing concept, competitive intensity and organisation performance. Journal of the Academy of Marketing Science, 15(3), p. 1-11.

McCarthy, E. J. and Perreault, W. D. (1984) Basic Marketing, (8 $8^{\text {th }}$ edition). Illinois: Richard D. Irwin, Inc.

Mcnamara, C. P. (1972) The present status of the marketing concept. Journal of Marketing, 36, January, p. 50-57.

Melville, N., Kraemer, K. and Gurbaxani, V. (2004) Information technology and organizational performance: an integrative model of IT business value, MIS Quarterly, 28(2), p. 283-322.

Michaels, R. E. and Day, R. L. (1985) Measuring market orientation of salespeop1e: A replication with Industrial buyers. Journal of Marketing Research, 22, November, p. 443-446.

Naidu, G. M. and Narayana, C. (1991) How marketing oriented are hospitals in a declining market. Journal of Health Care Marketing, 11(1), p. 23-30.

Narver, J. C. and Slater, S. F. (1990) The effect of a market orientation on business profitability. Journal of Marketing, October, p. 20-35.

Narver, J. C. and Slater, S. F. (1994) Market orientation, customer orientation value, and superior performance. Business Horizons, MarchApril, p. 22-28.

Nieboer, N. (2005) How strategic is housing asset management of institutional real estate investors? Property Management, 23(1), p. 22-32.

Nunally, J. C. (1978) Psychometric Theory (2 ${ }^{\text {nd }}$ edition), New York: McGraw Book Company.

Parasuraman, A., Valerie, A. Z. and Berry, L. L. (1985) A conceptual model of service quality and its implications for future research. Journal of Marketing, 49(fall), p. 41-50.

Peter, J. P. (1979) Reliability: A review of psychometric basics and recent marketing practice. Journal of Marketing Research, 16, February, p. 6-17.

Pitt, L., Caruana, A. and Berthon, P. R. (1996) Market orientation and business performance: some European evidence. International Marketing Review, 13(1), p. 5-18.

Reicheld, F. and Sasser, W. (1990) Zero defections come to the services. Harvard Business Review, Sept-October, p. 105-111.

Ruekert, R. and Walker, O. C. (1987) Marketing's interaction with other functional units: A conceptual framework and empirical evidence. Journal of Marketing, 51, January, p. 1-19.

Saxe, R. and Weitz, B. A. (1982) The SOCO Scale: A measure of the customer orientation of salespeople. Journal of Marketing Research, 19, August, p. 343-351.

Singh, S. (2003) Effects of transition economy on the market orientation - Business performance link: The empirical evidence from Indian industrial firms. Journal of Global Marketing, 16(4), p. 73-96.

Tay, L. (2002) Business performance of surveying firms: a data-driven path model. Journal of Property Research, 19(4), p. 327-351.

Tay, L. and Morgan, N. (2002) Antecedents and Consequences of Market Orientation in Chartered Surveying Firms. Construction Management and Economics, 20(4), p. 331-341.

Tse, C. B. (1998) Market orientation of large property companies in Hong Kong'. International Journal of Commerce Management, 8(1), p. 57-70.

Wind, Y. and Robertson, T. (1983) Marketing strategy: new directions for theory and research. Journal of Marketing, 47(spring), p. 12-25.

Zahra, S. A., Belardino, S. and Boxx, W. R. (1988) Organisational innovation: its correlates and its implications for financial performance. International Journal of Management, 5, June, p. $133-142$. 


\section{SANTRAUKA}

RINKOS ORIENTACIJA IR NEKILNOJAMOJO TURTO PLĖTROS VERSLAS SINGAPŪRE

\section{Jasmine Y. W. TAY, Linda TAY}

Nekilnojamojo turto plètros verslas dažnai laikomas itin rizikingu ir pelningu. Todèl būtina igyti konkurencinị pranašumą. Dalykinejje literatūroje rašoma, kad rinkos orientacija - tai subalansuoto konkurencinio pranašumo forma versle. Straipsnyje mėginama šį ryši patikrinti, nagrinejjant būtent itin rizikingą verslą, tokị kaip nekilnojamojo turto plètra. Sukurta rinkos orientacijos skale, kuria remiantis matuojamas rinkos orientacijos laipsnis nekilnojamojo turto plètros firmose. Rezultatai rodo, kad yra nemažas teigiamas ryšys tarp dviejų konkrečių rinkos orientacijos aspektų, t. y. orientacijos ị pelną ir reagavimo ị verslo rezultatus bei ị rinkodaros rezultatus. Be to, empirinés išvados rodo, kad rinkos orientacijos ryšys su rinkodaros rezultatais yra stipresnis nei su verslo rezultatais. 


\section{APPENDIX}

Market orientation scale

\begin{tabular}{|c|c|c|}
\hline Dimension & label & Question \\
\hline \multirow{8}{*}{$\begin{array}{l}\text { Customer } \\
\text { orientation }\end{array}$} & Cust_01 & We encourage customer comments and complaints because they help do a better job. \\
\hline & Cust_02 & After-sales service is not an important part of our business strategy. \\
\hline & Cust_03 & We have a strong commitment to our customers. \\
\hline & Cust_04 & $\begin{array}{l}\text { We are always looking at ways to create customer value in the properties that we } \\
\text { develop Residential /Commercial /Industrial) and the services that we provide (e.g. } \\
\text { Hotel services and property management services). * }\end{array}$ \\
\hline & Cust_05 & We do not measure customer satisfaction on a regular basis. \\
\hline & Cust_06 & Our firm would do a lot better if the sales force worked a bit harder. \\
\hline & Cust_07 & $\begin{array}{l}\text { In our company, marketing's most important job is to identify and help meet needs of } \\
\text { our customers. }\end{array}$ \\
\hline & Cust_08 & $\begin{array}{l}\text { We define quality as the extent to which our customers are satisfied with the properties } \\
\text { that we develop and the services we provide. }\end{array}$ \\
\hline
\end{tabular}

Competitor Comp_01 We regularly monitor our competitors' marketing efforts.

orientation Comp_02 We infrequently collect marketing data on our competitors to help direct our Marketing plans.

Comp_03 Our salespeople are instructed to monitor and report on competitor activity.

Comp_04 Our top managers often discuss competitors' actions.

Comp_05 We consider opportunities based on competitive advantage.

Inter- Intf_01 Marketing information is not shared with all departments.

functional Intf_02 Only some departments are involved in preparing business plans strategies.

co-ordination Intf_03 We do a good job integrating the activities of all departments.

Intf_04 When one department discovers something important about competitors, it is slow to alert other departments.

Intf_05 We regularly have inter-departmental meetings to discuss market trends and developments on a formal basis. *

Intf_06 Our marketing people regularly discuss customer needs with other departments.

Profit Prof_01

orientation

Prof_02

Prof_03

Responsive- Resp_01

ness

Resp_02

Resp_03

Resp_04

Resp_05

Resp_06

Resp_07
Our management information system can quickly determine the profitability of our different target market. *

Our management information system can quickly determine the profitability of properties that we develop and services that we provide. *

Our management information system can quickly determine the profitability of each property that we develop and each service that we provide. *

It takes us forever to decide how to respond to competitors' price changes. Somewhat, we tend to ignore changes to our customers' property/service needs. *

We periodically check our portfolio of investment properties and services we provide to assess whether they are in line with customer needs. *

Our business activities are driven more by cost savings in construction than by market research. *

The properties/services we sell are determined more by internal politics than real market needs. *

If a competitor launches an intensive campaign targeted at our customers we'll react immediately.

The activities of our departments are well-co-ordinated.

When we find that clients would like us to modify our service, facility/quality of our investment properties or designs for our new properties that is to be developed soon, the departments involved make concerted efforts to do so. * 